\title{
New distribution record of Cyathus stercoreus (Schwein.) De Toni (Nidulariaceae) for India from Gujarat state
}

\section{Patel RS, Vasava AM and Rajput KS}

Department of Botany, Faculty of Science, The Maharaja Sayajirao University of Baroda, Vadodara 390002, India

Patel RS, Vasava AM, Rajput KS 2018 - New distribution record of Cyathus stercoreus (Schwein.) De Toni (Nidulariaceae) for India from Gujarat state. Studies in Fungi 3(1), 227-233, Doi $10.5943 / \mathrm{sif} / 3 / 1 / 22$

\begin{abstract}
Cyathus stercoreus (Schwein.) De Toni (Nidulariaceae) was collected from Shoolpaneshwar Wildlife Sanctuary from the Narmada districts of Gujarat state, India. Present study reports $C$. stercoreus as a new distribution record from the Gujarat state. It was identified by using morphological features and further confirmation was carried out by using molecular methods with its DNA barcoding. Nucleotide sequence is submitted into NCBI and molecular data are submitted into BOLD data system for DNA barcoding.
\end{abstract}

Key words - Cyathus - DNA barcoding - Gujarat - Nidulariaceae

\section{Introduction}

The family Nidulariaceae have a gasteroid fruiting body (i.e. spores develop internally, as in an angiocarp) that are typically gregarious. It consists of five genera viz. Crucibulum, Cyathus, Mycocalia, Nidula, and Nidularia. All of members are distinguished from each other by their morphological characters and peridiole structure (Brodie 1975).

The genus Cyathus is easily distinguished from the other members of the family Nidulariaceae by the presence of grey to black peridioles with funicular cords and peridia composed with three layers of tissues (Brodie 1974, Brodie 1975, Brodie \& Sharma 1980, Das \& Zhao 2012, 2013, Lloyd 1906). The generic name was first introduced by Haller in 1768 and later it's adopted by Persoon (1801). Till date, available literature indicates that nearly 45 species of Cyathus are distributed worldwide (Brodie 1967, 1975, Kirk et al. 2008). On the other hand, studies carried out by Das et al. (2014), Sharma (2016) showed that nearly 17 species of Cyathus are distributed throughout India. Among them, Cyathus stercoreus is commonly known as the dungloving bird's nest fungi and prefers growing on dung, or soil containing dung. According to Peric \& Peric (2006) C. stercoreus is listed under the category of endangered species in a number of European countries.

The state Gujarat has different vegetation zone like moist deciduous forest (south Gujarat), dry deciduous to scrub forest in central and north Gujarat. Though the climatic conditions are favourable and unique for the luxurious growth of fungal flora; there are only few sporadic reports on fungal diversity for the state of Gujarat (Assudani et al. 2013, Bhavsar et al. 2012, Dhingani et al. 2013, Koyani et al. 2016, Nagadesi \& Arya 2014, Rajput et al. 2015, Vasava et al 2015, 2017). As a part of fungal diversity documentation, present study reports $C$. stercoreus as a new distributional record from Shoolpaneshwar Wildlife Sanctuary (Sagai, Gujarat state). 


\section{Materials \& Methods}

\section{Collection}

Fungal specimen was collected from Shoolpaneshwar Wildlife Sanctuary (Sagai forest, Gujarat), India). Fresh fruiting bodies were collected in sterile polyethylene bag for further taxonomic study. Field photographs were taken through Canon 1200 D. Morpho-taxonomical characters were observed for both fresh and dried sample. Macro-morphological characters of the fruiting bodies were observed under Leica stereo zoom Microscope. Distinguishing morphological and microscopical structures were noted using Leica DM 2000 trinocular research microscope. Mycelial characters as well distinctive features of fruiting body were studied and compared for identification with available literature (Das et al. 2014, Martin 1927, Sharma 2016, Thind 1977, Thind et al. 1984). Fruiting bodies were inoculated on PDA medium for mycelium development which will be further utilized for molecular identification of the species.

\section{DNA isolation and PCR}

Genomic DNA were extracted from fresh fruiting body and established pure culture of Cyathus stercoreus by using a Plant/Fungi DNA isolation kit (Sigma Cat\# E5038). The PCR reactions were performed in a $20 \mu \mathrm{l}$ volume containing 1x final concentration of DreamTaq Green PCR Master mix (Cat\# K1081), 50 ng of genomic DNA and 10 pmol of both universal primers ITS 1 and ITS 4 (White et al. 1990). PCR reactions were carried out using Veriti ${ }^{\circledR}$ thermal cycler (Applied BioSystems) under the following conditions: initial $94{ }^{\circ} \mathrm{C}$ for $4 \mathrm{~min}$, followed by 35 cycles of denaturation at $94{ }^{\circ} \mathrm{C}$ for $30 \mathrm{sec}$, annealing at $55^{\circ} \mathrm{C}$ for $30 \mathrm{sec}$ and extension at $72{ }^{\circ} \mathrm{C}$ for 1:30 min., with a final extension at $72^{\circ} \mathrm{C}$ for $10 \mathrm{~min}$. The PCR product was visualized on $2 \%$ agarose gel and amplified PCR product was purified using PurelinkTM Quick PCR Purification kit (Cat\# K310001).

\section{DNA sequencing}

Purified PCR product was sent for DNA sequencing to Eurrofins Genomics India Pvt. Ltd., Bangalore. The obtained sequences were compared with sequences available in the NCBI database using the Basic Local Alignment Search Tool. BOLD data system was used for generate DNA barcodes for nucleotides sequences.

\section{Results and Discussion}

Studies on fungal diversity of Gujarat state are rare, though it has several applications in wellbeing of the human being such as: source of various enzymes, bioremediation of xenobiotic compounds, in recycling of carbon stored in the form of cell wall constituents of plants (Wikclow et al.1980, Halsall 1993, Akin et al.1995, Kang et al.2007, 2008, Bhatt et al. 2016). Based on the various enzymatic studies, $C$. stercoreus is considered to be efficiently capable for the production of lignin and cellulose degrading enzymes (Halsall 1993, Akin et al. 1995, Sethuraman et al. 1999); antioxidant compounds (Kang et al. 2007, 2008); and also reported as a folk medicine (Bo \& Bu 1980).

Present study documents occurrence of $C$. stercoreus for the first time from Gujarat state. Its pure culture was successfully established on PDA medium (Fig. 1A, B) and maintained at $4{ }^{\circ} \mathrm{C}$ for further study. Morpho-taxonomic features of the species is as follows:

\section{Cyathus stercoreus (Schwein.) De Toni}

Nest up to $1.5 \mathrm{~cm}$ tall and 4-9 $\mathrm{mm}$ wide, cone-shaped or goblet-shaped, outer surface brownish, shaggy and hairy (Fig. 2A-C), inner surface lead-grey to black, smooth, bald, shiny, containing tiny blackish eggs (Figs. 1C-F, 2A-C).

Peridioles 1-2 mm in diam., lens-shaped, dark grey to black, attached to the nest by funicular cords (Fig. 1C). Funicular cord is attached at one end to the peridiole and at the other end to an 
entangled mass of hyphae i.e. hapteron (Fig. 1E, F). The spores are smooth, thick walled globose to oval and hyaline in outline.

Edibility - Inedible.

Occurrence and substrate - July to October, grows on dung of herbivores, humus rich soil and wood chips.
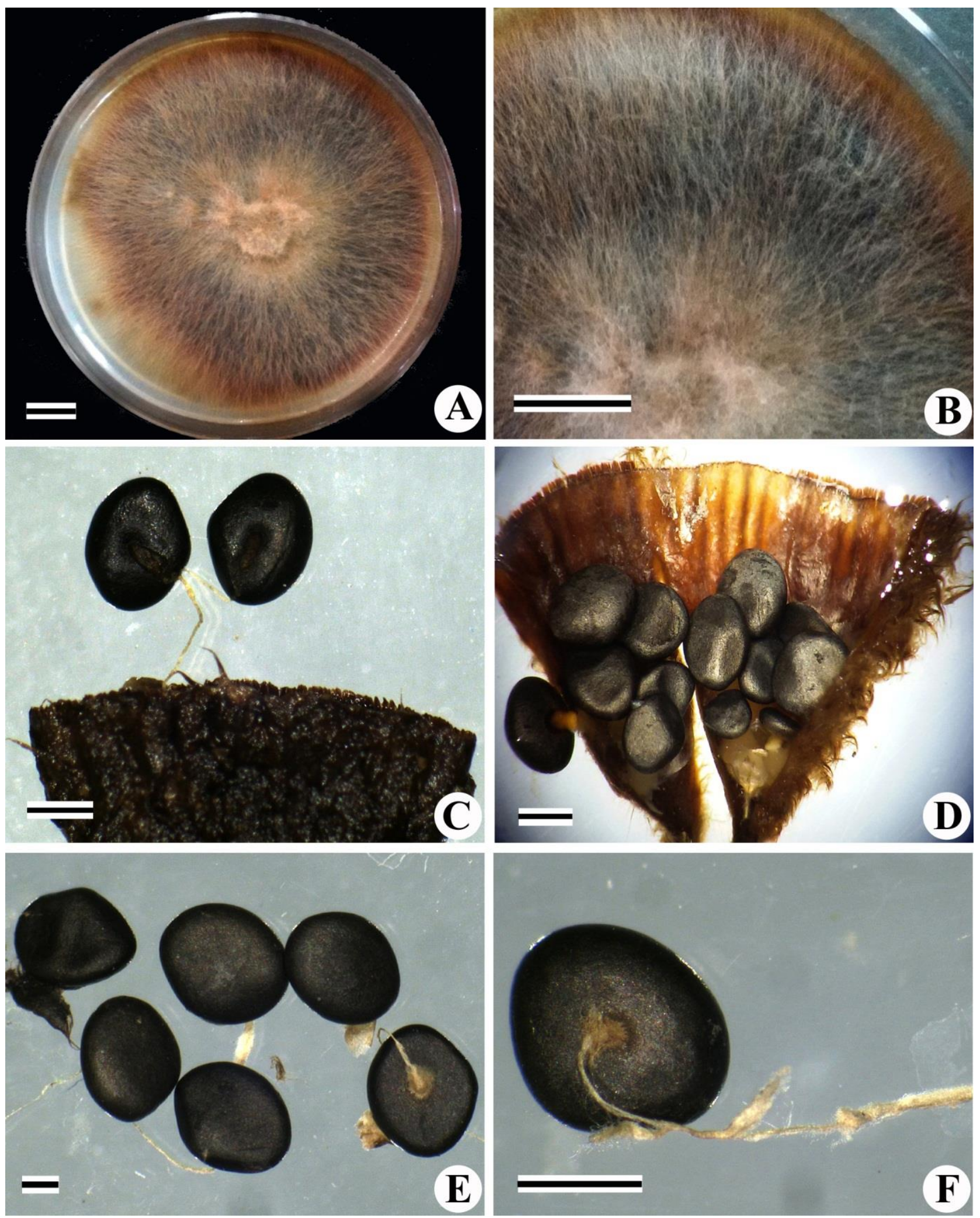

Fig. 1 - Cyathus stercoreus. A, B Mycelia cultures on PDA plate. C, D Section through longitudinal line of cup showing attached peridioles. E, F Peridioles with funicular cords Scale bars: $\mathrm{A}, \mathrm{B}=1 \mathrm{~cm}, \mathrm{C}, \mathrm{D}, \mathrm{E}, \mathrm{F}=1 \mathrm{~mm}$. 
Distribution - India, West Indies, Europe, New Zealand, Hawaii, Hawaiian Islands, United States and Canada. Although it is widespread in the tropics as well as in the temperate zones (Ahmad 1942, Brodie 1975, Das et al. 2014, Kirk et al. 2008, Peric \& Peric 2006).

Material examined - INDIA: Gujarat, Narmada districts, Shoolpaneshwar Wildlife Sanctuary

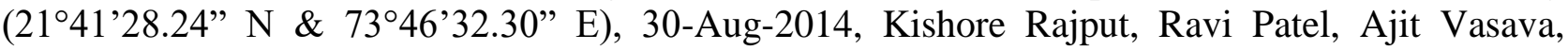
voucher number: KSR0002.
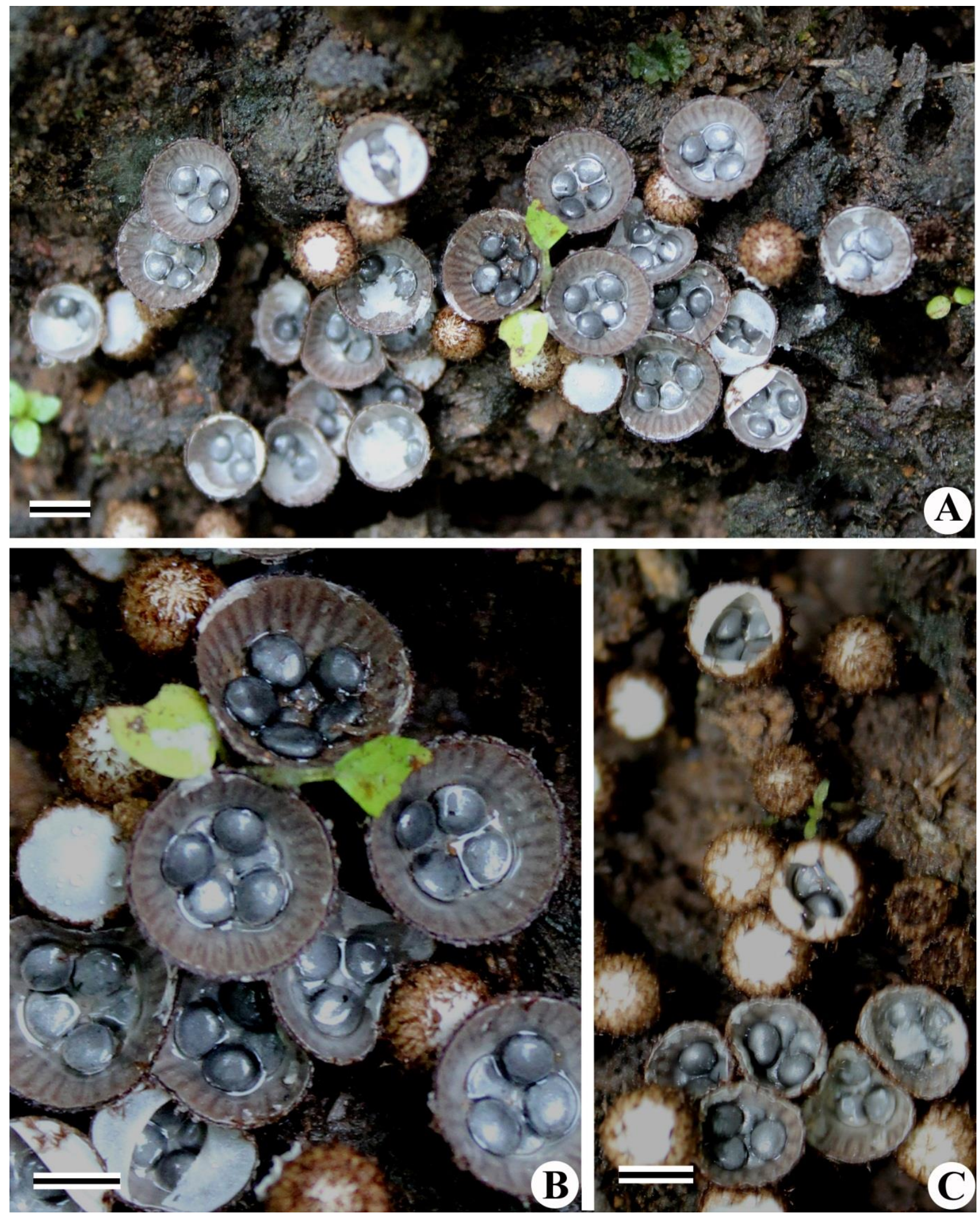

Fig. 2 - Cyathus stercoreus. A, B, C Morphology of fruiting bodies growing on dung. Scale bars: $\mathrm{A}, \mathrm{B}, \mathrm{C}=5 \mathrm{~mm}$. 


\section{Molecular Data}

The generated nucleotide sequence was used for BLAST search in the GenBank database (www.ncbi.nlm.nih.gov) for further confirmation of the species. Identification was done on the basis of $99 \%$ base pair match of the sequence obtained with the maximum scores for identity and Query coverage of the reference sequences from the NCBI database. Isolate KSRF-0002 of present study covered the maximum scores with $96 \%$ of identity and $95 \%$ of query coverage with Cyathus stercoreus (Accession no. KY706156) submitted by CRJ Hay 2017 as well as sequences deposited by the other authors viz. accession no FJ478125, KT365517, EU784192, EU784193 etc. Along with these mentioned sequences submitted by the other authors for C. stercoreous; When compared with above mentioned sequences, sequence generated in the present investigation showed $93 \%$ base pair match with $C$. striatus. Therefore, macro-morphological and microscopic features were compared with available literature (Martin 1927, Sharma 1982, 2016, Thind 1977, Thind 2005, Thind et al. 1984) for the accurate identification.

After the analysis of morpho-taxonomic features, it was observed that present specimens differ from $C$. striatus by presence of dark black peridiole; length wise fruiting body was not plicate, while size of the basidiospores much larger in C. strecoreus. All these morphological features are characteristic of the species C. strecoreus. Molecular confirmation also showed up to 95 to 96 percent match with $C$. stercoreus. Therefore, we conclude that present specimen is $C$. stercoreus and not $C$. striatus. Nucleotide sequence of $C$. stercoreus generated in the present study are submitted to NCBI database (accession no. MF506822, MH543350) and to BOLD Data system to generate DNA barcode for C. stercoreus (BOLD ID KSRF-0002).

\section{Acknowledgements}

Authors are thankful to Gujarat Biodiversity Board (GBB) for financial support and Range forest officers, Deputy Conservators of Forest, Government of Gujarat for necessary permissions.

\section{References}

Ahmad S. 1942 - Gasteromycetes of N.W. Himalayas-II. J. Indian bot. Soc 21, 283-293.

Akin DE, Rigsby LL, Sethuraman A, Morrison WH et al. 1995 - Alterations in structure, chemistry, and biodegradability of grass lignocellulose treated with the white-rot fungi Ceriporiopsis subvermispora and Cyathus stercoreus. Appl Environ Microbiol 61,591-1598.

Assudani HJ, Pandya JM, Sarvan RR, Sapre AM et al. 2013 - Etiological diagnosis of microbial keratitis in a tertiary care hospital in Gujarat. National Journal of Medical Research 3(1), 6062.

Bhatt IM, Pramod S, Koyani RD, Rajput KS. 2016 - Histological changes in the cell wall structure during wood decay by Trametes hirsuta and Trametes versicolor in neem (Azadirachta indica A. Juss). Journal of Sustainable Forestry 35(8), 578-590.

Brodie HJ. 1967 - Cyathus bulleri, a hitherto undescribed fungus of the Nidulariaceae from the West Indies. Bulletin of the Torrey Botanical Club 94, 68-71.

Brodie HJ. 1974 - A new plicate Cyathus from India. Can J Bot 52(1), 247-249.

Brodie HJ. 1975 - The bird's nest fungi. University of Toronto Press, Toronto and Buffalo, pp.199.

Brodie HJ, Sharma BM. 1980 - Cyathus griseocarpus, a new bird's nest fungus from India. Botaniska Notiser 133(3), 343-345.

Bo L, Bu YS. 1980 - Fungi Pharmacopoeia (Sinica). The Kinoko Company: Oakland, California. $246 \mathrm{pp}$.

Bhavsar HK, Modi DJ, Sood NK, Shah H. 2012 - A study of superficial mycoses with clinical mycological profile in tertiary care hospital in Ahmedabad, Gujarat. National Journal of Medical Research 2(2), 160-164.

Das K, Zhao R. 2012 - Bird's nest fungi in India: a new record from Sikkim. Biodiversity and taxonomy, New Delhi, India: Narendra Publishing House, pp. 61-68. 
Das K, Zhao R. 2013 - Nidula shingbaensis sp. nov., a new bird's nest fungus from India. Mycotaxon 125, 53-58.

Das K, Hembrom M, Parihar A, Zhao RL. 2014 - A new species of Cyathus (Agaricaceae) from India. Turk J Bot 40, 97-103.

Dhingani JC, Solanki KU, Kansara SS. 2013 - Management of root rot disease [Macrophomina phaseolina (Tassi.) Goid] of chickpea through botanicals and oil cakes. The Bioscan 8(3), 739-742.

Halsall DM. 1993 - Inoculation of wheat straw to enhance lignocellulose breakdown and associated nitrogenase activity. Soil Biol Biochem 25, 419.

Kang HS, Jun EM, Park SH, Heo SJ et al. 2007 - Cyathusals A, B, and C, antioxidants from the fermented mushroom Cyathus stercoreus. Journal of Natural Products 70(6), 1043-1045.

Kang HS, Kim KR, Jun EM, Park SH et al. 2008 - Cyathuscavins A, B, and C, new free radical scavengers with DNA protection activity from the Basidiomycete Cyathus stercoreus. Bioorganic \& Medicinal Chemistry Letters 18 (14), 4047-50.

Kirk PM, Cannon PF, Minter DW, Stalpers JA. 2008 - Ainsworth \& Bisbys's Dictionary of the Fungi, 10th Ed. CAB International, Wallinford.

Koyani RD, Patel HR, Vasava AM and Rajput KS. 2016 - Xylariaceae: Overview and addition to fungal diversity of Gujarat state. Studies in Fungi 1(1), 69-79.

Lloyd CG. 1906 - The Nidulariaceae or "Bird's Nest Fungi" Myc. Writ 2, 1-32.

Martin GW. 1927 - "Basidia and spores of the Nidulariaceae" Mycologia 19, no. 5 (1927): 239247.

Nagadesi PK, Arya A. 2014 - New records of lignicolous fungi from Ratanmahal Wildlife Sanctuary, Gujarat, India. International Letters of Natural Sciences 8, 23-29.

Peric B, Peric O. 2006 - The Provisory Red List iof Endangered Macromycets of Montenegro. In ECCF Newsletter 14, 19-21.

Persoon CH. 1801 - Synopsis methodica fungorum. Gottingae: 1-706pp.

Rajput KS, Koyani RD, Patel HP, Vasava AM, Patel R, Patel A, Singh AP. 2015 - Preliminary checklist of fungi of Gujarat state, Western India. Current Research in Environmental and Applied Mycology 5(4), 285-306.

Sethuraman A, Akin D, Eriksson KE. 1999 - Production of ligninolytic enzymes and synthetic lignin mineralization by the bird's nest fungus Cyathus stercoreus. Appl Microbiol Biotechnol 52(5), 689-97.

Sharma BM. 1982 - Studies on Gasteromycetes of Eastern Himalaya and adjoining hills. Ph.D. Thesis, Panjab University, Chandigarh. India.

Sharma BM. 2016 - Genus Cyathus Hallerex Pers. (Agaricomycetes) from Eastern Himalaya. Kavka 47, 20-26.

Thind IPS. 1977 - Studies on Gasteromycetes of North Western Himalaya. Ph.D. Thesis, Panjab University, Chandigarh. India.

Thind KS, Thind IPS, Sharma BM. 1984 - Gasteromycetes of the Himalayas-III. Kavaka 12, 5357.

Thind IPS. 2005 - Distribution of gasteromyceteous fungi in north western Himalayas. In: Dargan JS, Atri NS, Dhingra GS, editors. Fungi Diversity and Conservation in India, Dehradun, India: Bishen Singh Mahendra Pal Singh, pp. 183-191.

Vasava AM, Koyani RD, Singh AP, Rajput KS. 2015 - Diversity and distribution of myxomycetes in western part of India, with special reference to the state of Gujarat. Current Research in Environmental \& Applied Mycology 5(4), 382-389.

Vasava AM, Koyani RD, Patel R, Rajput KS. 2017 - Diversity and distribution of Agaricaceae in western part of India with special reference to Gujarat state. Journal of Indian Botanical Society 96 (1\&2), 119-135.

White TJ, Bruns T, Lee S, Taylor J. 1990 - Amplification and direct sequencing of fungal ribosomal RNA genes for phylogenetics. In: PCR Protocols: a guide to methods and 
applications. (Innis MA, Gelfand DH, Sninsky JJ, White TJ, eds). Academic Press, New York, USA: $315-322$.

Wikclow DT, Detroy RW, Jessee BA. 1980 - Decomposition of lignocellulose by Cyathus stercoreus (Schw.) de Toni NRRL 6473, a white rot fungus from cattle dung. Applied and Environmental Microbiology. 40(1), 169-170. 